\title{
EXCHANGE RATE EXPOSURE AND RISK MANAGEMENT: THE CASE OF JAPANESE EXPORTING FIRMS
}

\author{
Takatoshi Ito \\ Satoshi Koibuchi \\ Kiyotaka Sato \\ Junko Shimizu \\ Working Paper 21040 \\ http://www.nber.org/papers/w21040 \\ NATIONAL BUREAU OF ECONOMIC RESEARCH \\ 1050 Massachusetts Avenue \\ Cambridge, MA 02138 \\ March 2015
}

The authors would also appreciate the financial support of the JSPS (Japan Society for the Promotion of Science) Grant-in-Aid for Scientific Research; Ito for (A) -25245044; Koibuchi for Young Scientists (B) No. 23730307Sato for (A) No. 24243041 and (B) No. 24330101, and Shimizu for (C) No. 24530362. This survey is supported by the Research Institute of Economy, Trade and Industry (RIETI) and the Ministry of Economy, Trade and Industry (METI). We wish to thank all respondents of firms and RIETI staff for their kind help and cooperation. The views expressed herein are those of the authors and do not necessarily reflect the views of the National Bureau of Economic Research.

NBER working papers are circulated for discussion and comment purposes. They have not been peerreviewed or been subject to the review by the NBER Board of Directors that accompanies official NBER publications.

(c) 2015 by Takatoshi Ito, Satoshi Koibuchi, Kiyotaka Sato, and Junko Shimizu. All rights reserved. Short sections of text, not to exceed two paragraphs, may be quoted without explicit permission provided that full credit, including $(\mathrm{C}$ notice, is given to the source. 
Exchange Rate Exposure and Risk Management: The case of Japanese Exporting Firms

Takatoshi Ito, Satoshi Koibuchi, Kiyotaka Sato, and Junko Shimizu

NBER Working Paper No. 21040

March 2015

JEL No. F31,G15,G32

\begin{abstract}
$\underline{\text { ABSTRACT }}$
This paper investigates the relationship between the Japanese firms' exposure to the exchange rate risk and risk management, such as choice of invoicing currency, and financial and operational hedge. The firm's exposure to the exchange rate risk is estimated by co-movements of the stock prices and exchange rates, following Dominguez (1998) and others. Data on risk management measures-financial and operational hedging, the choice of invoice currency and the price revision strategy (pass-through)—were collected from a questionnaire survey covering all Tokyo Stock Exchange listed firms in 2009. Results show the followings: First, firms with greater dependency on sales in foreign markets have greater foreign exchange exposure. Second, the higher the US dollar invoicing share, the greater is the foreign exchange exposure. But, risk is reduced by both financial and operational hedging. Third, yen invoicing reduces foreign exchange exposure. These findings indicate that Japanese firms use the combination of risk management tools to mitigate the degree of the exchange rate risk.
\end{abstract}

Takatoshi Ito

Columbia University

School of International and Public Affairs

International Affairs Building

Room 927, (MC 3333)

420 West 118th Street

New York, NY 10027

and NBER

ti2164@columbia.edu

Satoshi Koibuchi

Chuo University

Faculty of Commerce

742-1 Higashi Nakano

Hachioji, Tokyo, 192-0393 Japan

koibuchi@tamacc.chuo-u.ac.jp
Kiyotaka Sato

Yokohama National University

Department of Economics, 79-3 Tokiwadai, Hodogaya-ku

Yokohama, 240-8501, Kanagawa

Japan

sato@ynu.ac.jp

Junko Shimizu

Gakushuin University

Faculty of Economics

1-5-1 Mejiro, Toshima-ku

Tokyo, 171-8588, Japan

Junko.Shimizu@gakushuin.ac.jp 


\section{Introduction}

A period of strong yen squeeze profits of Japanese exporters either by lower sales with higher prices, in case that yen appreciation is passed through to the retail prices in the destination market, or by a decline in the profit margin, in case that it is not passed through, in the destination market. Between 2008 and 2012, the yen appreciated vis-à-vis the US dollar by more than 30 percent. Since the yen was floated in 1973, Japanese firms have continuously concerned and struggled with the yen appreciation, and this time was no exception.

Various ways to manage foreign exchange risk have been developed by the Japanese exporters over the time. Even though some production bases have been moved abroad, significant production capacity remains in Japan. Those productions in Japan are still exposed to the exchange rate risk - a long-term yen appreciation trend and short-term volatility.

Japanese firms usually use both financial and operational hedges to manage their currency exposure. Financial hedges are conducted mainly with the use of currency derivatives, while operational hedges are devised in the firm's international transactions between the head office and foreign subsidiaries. With the development of financial hedge techniques, such as forward transactions, currency swaps, and currency options, firms can hedge their currency exposure against foreign exchange risks. However, these transactions, which determines the yen receipt with certainty if fully hedged, can be used only for the horizon of several months, and with some costs. Financial hedge cannot be effective in the long-run. In response to the unprecedented level of strong yen in the mid-1990s, Japanese exporting firms have accelerated moving and expanding production bases overseas. The firms have also increased the proportion of imported components from overseas and taken other counter measures to mitigate the damage from the stronger yen.

It is well-known that Japan is an outlier in the pattern of invoicing currencies. According to "stylized facts" of the choice of invoice currency, which were developed in the 1970s following the seminal work of Grassman (1973), trades between two economically advanced countries tend to be invoiced in the exporter's currency, and trade between economically advanced and developing countries is generally invoiced in the advanced country's currency. However, Japan's currency invoicing pattern differs from these stylized facts ${ }^{1}$. According to the Ministry of Finance data, Japanese exporters have a strong tendency to choose the importer's currency for their exports to advanced countries such as the US and EU. For exports to Asia, the US dollar, which is the currency of the third country, is commonly used. This is one of the reasons why currency risk management is a serious problem among the Japanese firms. If their exports

\footnotetext{
${ }^{1}$ Ito et al. $(2010,2012)$ investigate this puzzle by conducting and analyzing a series of interviews of representative exporters.
} 
were invoiced in the yen, their business performance would not have been affected as much as it has actually been during the strong yen periods. Besides invoicing, firms can change export prices, even if the invoicing currency is in the yen in the medium-term (in the next export contract period). How often the firms adjust the export prices in response to the exchange rate (i.e., pass-through), is a variable that the firms choose to decide. If firms are so competitive that they can raise their product prices to offset losses from yen appreciation, then the exchange rate fluctuations would not cause any severe impact on their profit performance. Accordingly, the medium-term effectiveness of exchange risk management depends on the choice of invoicing currency and the degree of pass-through, both of which depends on competitiveness of products.

Then, how can the effectiveness of Japanese firms' exchange rate risk management be measured? One possible way is to measure each firm's exchange rate exposure, and to investigate the relationship between the exchange rate exposure and the exchange rate risk management. We follow previous studies (such as Dominguez (1998) and Doukas (2003)) that have derived exchange rate exposure by estimating the sensitivity of firms' cash flows to the fluctuations in the exchange rate. The value of a firm is the present value of its future cash flow stream and the current exchange rate variation will affect the cash flows in the future. To date, many empirical studies have used stock returns as a proxy for the firm value, and have obtained exchange rate exposure from a regression of stock returns on an exchange rate change. Although the issue of how to measure firms' exposure to the exchange rate fluctuations has been investigated by many researchers in the field of corporate finance, few existing studies have specifically undertaken the firm level analysis of the exchange rate exposure and exchange rate risk management including the choice of invoice currency and pass-through policy.

In order to obtain information on how export firms are coping with the exchange rate fluctuation, an ad hoc questionnaire survey was designed and conducted with the cooperation of the Research Institute of Economy, Trade, and Industry (RIETI). Questionnaires were sent in September 2009 to 920 Japanese manufacturing firms. They were selected among those listed on the Tokyo Stock Exchange with a criterion that they reported foreign sales in the consolidated financial statements in fiscal year 2008 and 2009. Our sample firms are those that responded to the RIETI Survey 2009. The number of our samples is 227, spreading across 15 industries: Food, Textile, Chemicals, Medicinal Chemicals, Coal and Oil Products, Rubber Products, Glass and Stone Products, Iron and Steel, Non-Metal Products, Metal Products, General Machinery, Electrical Machinery, Transport Equipment, Precision Instruments and Other products. The response rate was $25 \%(=227 / 920)$. The questionnaire survey (hereafter, the 2009 RIETI survey) provided us with new information on Japanese firm's use of financial and operational hedging, price revision in response to the exchange rate changes, and choice of invoicing currency. The survey results are aggregated by industry and by the firm size, using 
annual financial reports of sample firms. See Appendix 1 for the basic information of responded firms.

Our analysis shows how Japanese firms combine three different tools of exchange rate risk management, such as operational and financial hedging, and exchange rate pass-through under their own choice of invoicing currency, to reduce their exchange rate exposure. Given a growing regional production network of Japanese firms, our findings based on the questionnaire study will present important implications for future exchange rate policies to support more effective exchange rate risk management.

The remainder of this paper is organized as follows. Section 2 reviews earlier literature of firms' foreign exchange risk management and presents a discussion of the relationship between the variety of exchange rate risk management and invoicing currency choice conducted by Japanese firms. Section 3 reviews the methodology of firm exchange rate exposure and presents our estimation results. Section 4 conducts empirical analyses to find the relation between exchange rate risk management and the exchange rate exposure. Finally section 5 concludes this paper.

\section{Exchange Rate Risk Management of Japanese Firms}

\section{2-1. Variety of Exchange Rate Risk Management}

Numerous empirical studies have examined the question of how firms accommodate or mitigate foreign exchange risk. Usually, firms use two means to hedge exchange rate risk. One is a financial hedge through financial market instruments such as exchange rate derivatives or foreign currency debt. The other is an operational hedge through operational organization of the exporting firm. To manage long-term exchange rate risks effectively, firms should build operational hedging strategies in addition to widely used financial hedging strategies. Most studies specifically examine currency hedging ${ }^{2}$. These studies analyze the relation between operational hedging and financial hedging and underscore the effectiveness of both strategies by conducting empirical analysis based on firms' stock return. For example, Pantzalis, Simkins, and Laux (2001), using a sample of 220 US multinational firms, and find that operational and financial hedges are complementary risk management strategies. Hommel (2003) shows that operational hedging creates flexibility, a strategic complement to financial hedging. Allayannis, Ihrig and Weston (2003) also investigate both financial and operational exchange-rate risk

\footnotetext{
${ }^{2}$ For example, Carter, Pantzalis, and Simkins (2001) investigate the impact of firmwide risk management practices for US multinational corporations and find that currency risk can be reduced effectively through transactions in the forward exchange market.
} 
management strategies of multinational firms and confirm that operational hedging strategies benefit shareholders only when used in combination with financial hedging strategies. Kim, Mathur and Nam (2006) investigate how operational hedging is related to financial hedging. They confirm that although operational and financial hedging strategies are complementary, firms using operational hedging are less dependent on the use of financial derivatives ${ }^{3}$.

The relationship between invoicing currency and hedging is rarely investigated. The exception was a study by Döhring (2008), which was the first reported survey study of both the choice of invoicing currency and financial/operational hedging. Results show that invoicing choice is a substitute for derivative hedging such as exchange rate forward in eliminating transaction risk and also that firms are expected to opt for either of them depending on the relative cost of the strategy. Conducting a survey of actual hedging strategies and techniques of large corporations from a euro-area perspective, Döhring (2008) concludes that whether a domestic currency invoicing and hedging are substitutes or complements depends crucially on the size and geographical orientation of the exporting firm and on the structure of the destination market. ${ }^{4}$

As for recent country-specific studies, Chiand and Lin (2007) examine financial and operational hedge strategies of foreign exchange exposures using multiple-horizon data of Taiwan non-financial firms during 1998-2005. They report that the use of operational hedging strategies does not help reduce foreign exchange exposure for Taiwan firms. Pramborg (2005) compares the hedging practices between Swedish and Korean nonfinancial firms and shows that Korean firms used much smaller financial derivatives than Swedish firms with more dependence on foreign debt than derivatives. Both studies describe the difficulties of exchange rate risk management in underdeveloped foreign exchange markets such as those of Taiwan and Korea. Regarding research using data for Japan, Jayasinghe and Tsui (2008) examine the exchange rate exposure of sectoral indexes in Japanese industries and report evidence of exposed returns and its asymmetric conditional volatility of exchange rate exposure using a bivariate GJR-GARCH model. Although Japanese exporting firms tend to face large volatility of the yen/US dollar exchange rate, surprisingly few studies conduct firm level analysis of hedging and exchange rate risk management with the choice of invoicing currency.

\section{2-2. Japanese Firms' Feature of Currency Invoicing and Pass Through}

\footnotetext{
${ }^{3}$ They use a sample of 424 firm observations from the COMPUSTAT Geographic Segment files for 1998.

${ }^{4}$ Regarding the relation between pass-through and hedging, Bartram, Brown and Minton (2010) shows empirically that firms pass-through some porting of currency changes to customers and use both operational and financial hedges for the rest of the foreign exchange exposure.
} 
According to the "stylized facts" related to the choice of invoice currency, which is based on the seminal work of Grassman (1973), trade between two economically advanced countries tends to be invoiced in the exporter's currency. Trade between economically advanced and developing countries is generally invoiced in the advanced country's currency. However, Japan's currency invoicing pattern evidently contradicts the stylized facts. First, Japanese exporters have a strong tendency to choose the importer's currency for their exports to other advanced countries such as the United States and EU. Second, US dollar invoicing is prevalent in Japan's exports to Asia.

Many determinants of currency invoicing have been suggested in the literature. The authors typically use data of the share of currency invoicing at a country level, and correlate them with suspected macroeconomic factors. A micro-analysis at the firm level is needed to test the relevance of the factors. Only a few exploited the firm level data. Goldberg and Tille (2009) used highly detailed Canadian import data at a customs level with rich information on the source country, invoice currency, value of transactions, etc. The other is a study by Friberg and Wilander (2008), who conduct a questionnaire survey analysis with Swedish exporting firms for empirical tests on determinants of currency invoicing, which is a useful approach to obtain detailed data at a firm level.

Another exception is Ito et al. (2010b) who conducted an interview survey of leading Japanese exporters to overcome a data constraint ${ }^{5}$. As the interview survey recovers firm-level information related to exchange rate risk management, the destination breakdown with respect to the choice of invoice currency became possible. Also, one question was to reveal whether trades are intra-firm transactions or arms-length transactions - a clear advantage over macro data. Ito et al. $(2010,2012)$ claimed to have found evidence of a wider set of invoice currency determinants for the Japanese exporters: (1) Intra-firm trade, inter-firm trade, or trade via a trading company; (2) transaction cost of the currency; (3) the intensity of competition in the export destination markets and the degree of product differentiation; and (4) the structure of production and distribution network, in which, for example, goods are produced in Japanese exporters' subsidiaries in Asia and shipped to the United States as the final destination.

Intra-firm trade means, for example, the head office in Japan sells automobiles to foreign subsidiaries in the US and European countries. It was found that invoicing in the importer's currency is prevalent for Japanese intra-firm exports to advanced countries. Since the exports are destined for local subsidiaries that face severe competition in the local markets, Japanese parent firms have a strong tendency to take an exchange rate risk by invoicing in the importer's currency. In fact, it is a rational decision of headquarter to assume all currency risk for its

\footnotetext{
${ }^{5}$ Ito et al. (2010b) interviewed treasurers of 23 Japanese companies from four major export industries (automobile, electrical machinery, general machinery, and electronic components) over the one-year period of autumn 2007 - autumn 2008.
} 
exports to foreign subsidiaries in different currency areas, because headquarter is better equipped with managing multi-currency risk and with scale economies. Especially if the local subsidiaries, say in Asia, assembles cars and they sell to the US markets, then their choice of US dollar invoicing is rational as a part of their strategy of global exchange rate risk management.

Some Japanese firms that export highly differentiated products or which have a dominant share in global markets tend to choose yen invoicing. In addition, small firms, which have no treasury department because of budget constraints, usually ask a general trading company to manage their foreign exchange business. In this case, they also tend to use yen invoicing in their transactions with a trading company; and the trading company, which do both imports and exports, take over exchange rate risks. Accordingly, Japanese firms' choice of invoice currency is rather complicated, but should be considered along with other risk management tools.

As in Bartram, Brown and Minton (2010), we assume that Japanese firms have four options in managing exchange rate risk: (1) choice of invoice currency, (2) pricing (pass-through) policy, (3) operational hedging, and (4) financial hedging. Figure 1 shows our conceptual diagram of exchange rate risk management, based on which we constructed questions in the 2009 RIETI survey. We are able to clarify the notable characteristics of Japanese firms' exchange rate risk management based on the survey. Compared with the related studies above, the novelty of this paper is that it describes detailed empirical analysis of the exchange rate risk management of Japanese firms using the four different tools: invoicing currency choice, pricing (pass through) strategy, operational hedging and financial hedging.

\section{2-4. Effectiveness of the Japanese Firms' Exchange Rate Risk Management}

\section{Choice of invoicing currency}

As shown in Ito et al. (2010), Japanese firms that export highly differentiated products and/or have a dominant share in global markets tend to choose yen invoicing. If their exports are invoiced in the yen instead of the US dollar, their business performance would not be affected by a stronger yen at least for a short-time horizon. However, most firms do not have products that are sufficiently competitive to insist on the yen invoicing to the foreign buyers. In general, firms that cannot make exports totally yen invoiced rationally choose risk-mitigating measures depending on many factors. Factors such as firm size, products, trading partners, trading countries, and financial characteristics are suspected to influence the counter-measures to exchange rate risk.

\section{With an operational hedge ("marry and netting")}

In the wake of a sharp yen appreciation in 1995, Japanese exporting firms have accelerated 
transfer and expansion of production facilities overseas and increased the proportion of imported components from overseas. An increase in import components are considered to an example of "marry and netting", or part of the so-called "operational hedging." For firms with higher US dollar invoicing share, "marry and netting" presumably works effectively to reduce currency exposure. However, not all firms can use this technique. Firms that produce goods made using Japanese materials only and export them abroad cannot do marry or netting because they have no payable foreign currency. In the RIETI 2009 questionnaire, firms are asked whether they engage in "marry and netting" or more broadly, operational hedging.

\section{Degree of financial hedge (hedging ratio of forward contract)}

For firms that have little imported components, another instrument to hedge is financial hedge. It is expected that the higher the US dollar invoicing share is, the greater is the financial hedge usage to reduce the exchange rate exposure. In the RIETI 2009 survey, firms were asked whether they engage in financial hedge, and what type of financial instruments they used. More than $70 \%$ of firms are found to use some kind of hedging instrument through the foreign exchange market. Among them, more than $90 \%$ of firms use "forward contracts". However, no specific hedging ratio of "Forward contract" exists by industry or firm size. It seems that the hedging ratio depends on each firm's ability and willingness of the foreign exchange risk management.

\section{Exchange rate pass through}

Even when Japanese firms invoice their exports in the US dollar and suffer shrinking profit margins from yen appreciation, Japanese firms may be able to recover profit margin by raising the dollar-denominated export prices. This cannot be done too often, but a quarterly revision of export prices seem to be commonly done. When new models and makes are marketed, prices can easily reflect new exchange rate levels. Whether firms can make their price revisions in response to foreign exchange fluctuations (i.e., foreign exchange "pass through" occurs) and how frequently they do so determine the resilience of exporting firms against the exchange rate fluctuations. If products are sufficiently competitive to revise their prices to maintain their constant earnings in terms of the Japanese yen, then foreign exchange fluctuations can cause no long-term impact on their profit performance. Since the RIETI 2009 survey was conducted in the timing of having experienced a sharp yen appreciation, a question on the price revision in recent months reveals the firms' response to yen appreciation. An expected result is that firms with yen invoicing tended not to change export prices, while firms with dollar invoicing tended to have made price revisions. 


\section{Estimating Japanese Firms' Exchange Rate Exposure}

Many researchers empirically have investigated the exchange rate exposure of firms. Most of them measure the exposure as the sensitivity of firm's value to exchange rate fluctuations. Because the value of the firm is the discounted present value of its future cash flow streams, expectations of business environments including the exchange rate changes are regarded to influence the present firm value. Many empirical studies have used stock returns as a proxy for the change in the value of the firm, and we follow the tradition. The exchange rate exposure is measured as the coefficient of the exchange rate changes in the regression of stock price returns.

Traditionally, most Japanese firms have adopted various exchange rate risk management tools because of their high share of US dollar invoicing and a trend of yen appreciation. Several previous studies have specifically examined Japanese firms. Dominguez (1998) examined the exchange rate exposure of the Japanese main industries during the period of 1984-1995 and found that many Japanese companies are exposed to yen-dollar exchange rate movements. Their results imply that they do not fully hedge against exchange rate risk. He and $\mathrm{Ng}$ (1998) investigated a sample of 171 Japanese multinational firms' stock price returns for the period of January 1979 - December 1993 and found that the exchange rate exposure increases with the firm's export ratio and decreases with the level of hedging activity. ${ }^{6}$ Doukas et al. (2003) examined the exchange rate exposure for 1,079 firms traded on the Tokyo stock exchange during the period of 1975-1995 and confirmed that the exchange rate exposure is found to be positively associated with the degree of the firm's foreign business activities and that it is inversely related to its size and debt-to-asset ratio.

Among the models of previous studies, the simplest model is that of Adler and Dumas (1984), who define the exchange rate exposure as the change in the market value of the firm resulting from a unit change in the exchange rate. According to them, the exchange rate exposure of the firm is obtainable from the coefficient on the exchange rate variable as follows.

$$
R_{i, t}=\beta_{0, i}+\beta_{1, i} \cdot \Delta s_{t}+\varepsilon_{i, t}
$$

where $R_{i, t}$ is the stock return for firm $i, \Delta s_{t}$ is the percentage change in an exchange rate variable, defined as the home currency price of foreign currency, and $\beta_{1, i}$ is the elasticity of firm value to the exchange rate change. This elasticity indicates the firm's average exchange rate exposure over the estimation period, in home currency units, as a percentage of the firm's market value.

To control for other macroeconomic factors on realized returns, most empirical studies include a return to a market portfolio in the regression model. For example, Dominguez and

\footnotetext{
${ }^{6}$ In addition, they confirmed that keiretsu multinational corporations are more exposed to exchange-rate risk than non-keiretsu firms are.
} 
Tesar (2006) and many other related studies estimate controlling for macroeconomic factors using market portfolio as follows.

$$
R_{i, t}=\gamma_{0, i}+\gamma_{1, i} \cdot \Delta s_{t}+\gamma_{2, i} \cdot R_{m, t}+\varepsilon_{i, t}
$$

where $R_{m, t}$ is the return on the market portfolio and $\gamma_{1, i}$ is the elasticity of firm value to the exchange rate change adjusted by the firm's market portfolio.

Although most studies choose a regression model (2) to estimate Japanese firms' exchange rate exposure, with the Tokyo Stock Price Index (TOPIX) being a market portfolio, two problems exist in model (2). First, because TOPIX is correlated strongly with the dollar/yen rate, the two-factor regression model has a multicollinearity problem. Second, Bodnar and Wang (2003) warned that the market portfolio variable strongly influences the results, and that it sometimes put a downward bias on the coefficient and lowers the significance level ${ }^{7}$.

In the paper, we estimate the sampled firms' exchange rate exposure using two different models above on a monthly basis. Following Bodnar and Wang (2003), we refer to $\beta_{1, i}$ as the total exchange rate exposure and $\gamma_{1, i}$ as the residual exchange rate exposure. For the exchange rate measure, we alternatively use the nominal exchange rate (Japanese yen per US\$, or USD/JPY in the currency pair code name) and nominal effective exchange rate (NEER) published by BIS. Since an increase in the number of USD/JPY is yen depreciation, while an increase in the number of NEER (defined by BIS) is yen appreciation, we define the percentage change of BIS with an opposite sign. Hence, in both cases, an expected sign of $\beta$ and $\gamma$ are positive. For a market portfolio, we alternatively use TOPIX and MSCI Japan Index. ${ }^{8,9}$ where the latter may be better than the former, as the TOPIX is correlated strongly with the nominal exchange rate of the Japanese yen per US\$ (USD/JPY), causing the downward bias of the key coefficient.

The sample period for regressions is from January 2005 to December 2009. All but 2 of the estimated coefficients have expected signs and two coefficients with the wrong sign are statistically insignificant for both the USD/JPY regression and the NEER regression. ${ }^{10}$.

\footnotetext{
${ }^{7}$ Bodnar and Wang (2003) demonstrate that different constructions of a market portfolio have different exposures to exchange rates because of a significant size effects in exchange rate exposures. They propose the use of cap-based portfolios as controls for market factors.

8 The MSCI Japan Index is a free-float adjusted market capitalization weighted index that is designed to track the equity market performance of Japanese securities listed on Tokyo Stock Exchange, Osaka Stock Exchange, JASDAQ and Nagoya Stock Exchange. The MSCI Japan Index (Price Index) is calculated in JPY on a real time basis.

${ }^{9}$ Following the suggestion of Dominguez and Tesar (2006), we try to use an international index (MSCI World Price Index) by calculating the return in terms of the Japanese yen as a control variable. The estimated results are almost equal to those of the MSCI Japan Index.

${ }^{10}$ For these analyses, we use all estimated coefficients, either significant or not significant. Although some previous studies have devoted attention to statistical significance. We might lose the case of small exchange rate exposure from our sample. For a robustness check, we conduct the same
} 
Figure 2 shows the estimated total exchange rate exposure using the yen/dollar exchange rate and NEER by BIS. On average, their size is larger than $100 \%$ except for "Food" and "Medicinal Chemicals". Among the fifteen industries, the total exchange rate exposure of "Transport Equipment" is the highest and above 200\%. This result indicates that the exchange rate risk of "Transport Equipment" industries is larger than other industries and their stock return is affected more than twice of exchange rate change. Except for "Coal and Oil Products", the exchange rate exposures estimated by NEER are higher than those of the yen/dollar exchange rate. This result suggests that most Japanese industries face not only the fluctuation risk of the yen/dollar exchange rate, but also other trade countries' exchange rates.

Figure 3 presents the estimated residual exchange rate exposures using the yen/dollar exchange rate and NEER. All are less than $100 \%$ and are smaller than the total exchange rate exposure. Similar to the previous case, the residual exchange rate exposure of "Transport Equipment" is the highest among 15 industries. The second is "Precision Instruments", and "Electric Machinery" and "General Machinery" are the next except for "Other Products". These results are consistent with the fact that such Japanese representative manufacturing industries are facing severe competition with other countries.

Contrary to the findings of previous figure, results of the size of two residual exchange rate exposures differ by industry. The residual exchange rate exposures estimated by NEER are larger than those of yen/dollar exchange rate in "Food", "Medicinal Chemicals", "Iron and Steel", "Metal Products", "General Machinery", "Electric Machinery", "Transport Equipment", "Precision Instruments" and "Other Products". It is particularly interesting that the residual exchange rate exposures estimated by yen/dollar exchange rate are greater than those of NEER in more basic material industries such as "Coal and Oil Products", "Glass and Stone" and "Non Metal Products". The estimated results controlled by TOPIX are mostly similar to those by the MSCI Japan index.

\section{Determinants of firms' foreign exchange exposure}

In this section, we investigate the relationship between the estimated exchange rate exposure and exchange rate risk management of Japanese firms based on the questionnaire survey. As we presented in the section 2, the RIETI Survey 2009 covers rich information related not only to the firms' foreign exchange rate risk management but also to the firms' choice of invoicing currency and price revision (pass-through) strategy. The survey results are classified by industry and by the firm size, using annual financial reports of sample firms, through which

analysis using statistically significant coefficients only. We confirm that we obtained similar results. 
new evidence of Japanese firm's exchange rate risk management, such as the usage of financial and operational hedging and price revision, are presented.

Our hypotheses with respect to firms' exchange rate risk management are as follows:

1. Large share of foreign sales to total sales increases the exchange rate exposure.

2. High share of US\$ invoicing increases the exchange rate exposure.

3. Financial and operational hedges reduce the exchange rate exposure.

4. Financial and operational hedges can be effective in reducing exchange rate exposure, especially for a firm that chooses mainly US\$ invoicing.

5. High share of yen invoicing decreases the exchange rate exposure.

6. Frequent price revision to make pass through decreases exchange rate exposure.

Hypotheses 1 and 2 are examined in many previous studies. For example, Shapiro (1975), Levi (1983), and Jorion (1990) confirmed that the firm's currency exposure should be positively related to the ratio of foreign sales to total sales and the use of foreign currency hedging lessen a firm's foreign exchange rate exposure. Hypothesis 3 is also tested in many previous studies. For example, Bartram, Brown and Minton (2010) demonstrate that financial hedging with foreign currency-denominated debt appears to have a larger effect on exposure than the use of foreign exchange derivatives. Our contribution and novelty are in Hypotheses 4 and 5, which examine the effectiveness of financial and operational hedge with the choice of invoicing currency.

As a dependent variable, we use the estimated exchange rate exposures of four kinds in section 3 as follows:

- $\quad \beta^{\text {Total,JPY/USD }} i, \beta^{\text {Total,NEER }} i$ : Firm $i$ 's total exchange rate exposure obtained using nominal exchange rate of yen/dollar and NEER, respectively;

- $\quad \beta^{\text {Residual,JPY/USD }} i, \beta^{\text {Residual,NEER }} i$ : Firm $i$ 's residual exchange rate exposure obtained by TOPIX/MSCI Japan Index and nominal exchange rate of yen/dollar and NEER, respectively

As the basic explanatory variables in the right-hand-side, we first include a "size" of firm $i$, measured by the log of total consolidated sales, and "share of foreign sales," measured by total foreign sales of firms $i$ divided by total consolidated sales. Additionally, we use each firm's share of US dollar invoicing, i.e., the firm's answer in the RIETI 2009 Survey and four dummy variables: A dummy variable for using marry/netting (Dummy of $\mathrm{OH}$ ) takes 1 if a firm uses marry/netting and 0 if not. A dummy variable for using forward transaction (Dummy of $\mathrm{FH}$ ) takes 1 if a firm uses forward transaction and 0 if not. A dummy variable for executing price revision in 2008 (Dummy of PT) takes 1 if a firm revised the price attributable to the sudden appreciation of the Japanese yen and 0 if not. As another invoicing share variable, we also use a "dummy of USD Main Invoicing (yen Main Invoicing)," which takes 1 if the share of USD 
(yen) invoicing is larger than yen (USD) invoicing. ${ }^{11}$ First, we examine the determinants of exchange rate exposure including the share of US dollar invoicing in the following regression model.

$$
\begin{aligned}
& \beta^{\text {Total, JPY/USD }_{i}=\alpha_{0}+\alpha_{1} \text { Log of Total Consolidated Sales }}+\alpha_{2} \text { Share of Foreign Sales }_{i} \\
& +\alpha_{3} \text { Share of US Invoicing } \\
& +\alpha_{4} \text { Dummy of } \mathrm{OH}_{i}+\alpha_{5} \text { Dummy of } \mathrm{FH}_{i}+\alpha_{6} \text { Dummy of } P T_{i} \\
& +\alpha_{7} \text { Share of US Invoicing }{ }_{i} \text { Dummy of } \mathrm{OH}_{i} \\
& +\alpha_{8} \text { Share of US Invoicing } i \text { Dummy of } \mathrm{FH}_{i} \\
& +\gamma_{\mathrm{i}} \text { Industry dummy }_{j} \quad(j=1, \cdots, 15) \\
& \beta^{\text {Residuall, JPY/USD }} i=\alpha_{0}+\alpha_{1} \text { Log of Total Consolidated Sales }{ }_{i}+\alpha_{2} \text { Share of Foreign Sales }_{i} \\
& +\alpha_{3} \text { Share of US Invoicing } \\
& +\alpha_{4} \text { Dummy of } \mathrm{OH}_{i}+\alpha_{5} \text { Dummy of } \mathrm{FH}_{i}+\alpha_{6} \text { Dummy of } P T_{i} \\
& +\alpha_{7} \text { Share of US Invoicing }_{i} \cdot \text { Dummy of } \mathrm{OH}_{i} \\
& +\alpha_{8} \text { Share of US Invoicing }_{i} \cdot{\text { Dummy of } F H_{i}} \\
& +\gamma_{\mathrm{i}} \text { Industry dummy }_{j} \quad(j=1, \cdots, 15)
\end{aligned}
$$

The estimated results are presented in Table 1. As expected, the coefficients of the share of foreign sales are positive and statistically significant in all cases. The large share of foreign sales to total sales increases the exchange rate exposure. The coefficients of share of USD invoicing and "mainly-USD-invoicing" in the regression are positive and statistically significant in several cases, suggesting that once US-invoicing (or not yen-invoicing) is chosen, it is very difficult to completely offset the exchange rate exposure by other mitigating measures, such as operational and financial hedge. Contrary to our hypothesis 3, the coefficients of operational hedge and financial hedge are not negative. Some of the coefficients of financial hedging are positive and statistically significant. In these cases, the cross-term coefficients of financial hedge and USD invoicing (or USD main invoicing) are negative and statistically significant in most cases. These results suggest that firms with a high US\$ invoicing share can reduce their exchange rate exposure using financial hedging. It is particularly interesting that the cross-term coefficients of operational hedge and mainly-USD-invoicing are negative and statistically significant in the exchange rate exposure obtained by the yen/dollar exchange rate. The implication is that the exchange rate exposure obtained by the yen/dollar exchange rate can be reduced by a combined strategy of USD main invoicing and "marry and netting." Unfortunately, the coefficients of pass through are not significant.

${ }^{11}$ Descriptive statistics of all variables are presented in the Appendix 2. 
Second, we examine the determinants of exchange rate exposure including the share of yen invoicing in the following regression model.

$$
\begin{aligned}
& \beta^{\text {Total, JPY/USD }_{i}}=\alpha_{0}+\alpha_{1} \text { Log of Total Consolidated Sales }{ }_{i}+\alpha_{2} \text { Share of Foreign Sales }_{i} \\
& +\alpha_{3} \text { Share of Yen Invoicing } \\
& +\alpha_{4} \text { Dummy of } \mathrm{OH}_{i}+\alpha_{5} \text { Dummy of } \mathrm{FH}_{i}+\alpha_{6} \text { Dummy of } P T_{i} \\
& +\gamma_{\mathrm{i}} \text { Industry dummy } \text { dum }_{j} \quad(j=1, \cdots, 14) \\
& \beta^{\text {Residual, JPY/USD }} i=\alpha_{0}+\alpha_{1} \text { Log of Total Consolidated Sales } s_{i}+\alpha_{2} \text { Share of Foreign Sales }_{i} \\
& +\alpha_{3} \text { Share of Yen Invoicing } \\
& +\alpha_{4} \text { Dummy of } \mathrm{OH}_{i}+\alpha_{5} \text { Dummy of } \mathrm{FH}_{i}+\alpha_{6} \text { Dummy of } \mathrm{PT} \\
& +\gamma_{\mathrm{i}} \text { Industry dummy }_{j} \quad(j=1, \cdots \cdot 14)
\end{aligned}
$$

For an invoicing variable, we also use "Dummy of Yen Main Invoicing" in which the share of yen invoicing is larger than that of USD invoicing.

Estimated results are presented in Table 2. As expected, the coefficients of both "share of yen invoicing" and "mainly-yen-invoicing" are negative and significant in most cases. It is confirmed that the high share of yen invoicing decreases the exchange rate exposure.

In sum, Japanese firm's exchange rate exposure is found to be positively related to the share of foreign sales to total sales. As expected, firms with higher ratios of US dollar invoicing have higher degrees of exchange rate exposure as measured in the stock market. It is possible to mitigate the exchange rate exposure of the yen/dollar exchange rate by engaging in operational hedging and that of the NEER by financial hedging. This result is consistent with the conclusion of Ito et al. (2011). Furthermore, firms with yen invoicing have lower exchange rate exposure measured in the stock market. Price revision (pass-through) theoretically reduces a firm's total exchange rate exposure, but it is not found to be statistically significant in the regression.

\section{Conclusion}

This paper analyzed relationship between the Japanese firms' exchange rate risk management based on the 2009 RIETI survey and the exchange rate risk exposures that is estimated as the sensitivity of stock price movements to the exchange rate movement. Empirical results confirm the following characteristics. First, large Japanese manufacturing industries have a significant exposure to the exchange rate risk. Second, firms with greater dependence on foreign sales have a larger foreign exchange exposure. Third, the higher the US dollar invoicing ratio, the greater the foreign exchange exposure, but risk is reduced by financial and operational hedging. Fourth, yen invoicing reduces the foreign exchange exposure. Theoretically, in the 
medium run, the firms with large currency risk revise the export prices to partially counter losses from yen appreciation. However, this was not confirmed by the data.

Most of results obtained are consistent of conventional wisdom. However, it is a novel finding that those firms employing currency hedge and choosing yen invoicing are judged by the market to have reduced currency exposures. It is also found that Japanese firms do use operational and financial hedging strategies.

This is the first detailed investigation of the exchange rate risk management policy of Japanese firms, which was made possible by the newly conducted survey. These findings suggest important implications and tools for Japanese firms' exchange rate risk managers to build more efficient risk management schemes.

The questionnaire method has well-known limitations as well as benefits. Supplementary sources such as firms' financial reports are used to strengthen the analysis. For example, the listed firms' exchange rate exposure is estimated from their financial statements, and it is compared against their exposure and risk management from the survey. It is left for a future analysis whether we can obtain the same results if we add other control variable, such as foreign debt ratio, $R \& D$ investment, volatility of (foreign) sales, and number of foreign subsidiary and production base. We use only "marry and netting" as a proxy of operational hedges. However, firms have more tools in the menu under operational hedges. 
References

Adler, M., and Dumas, B., 1984. "Exposure to currency risk: definition and measurement," Financial Management 13, 41-50.

Allayannis, G., Ihrig, J. and Weston, J. P., 2001, "Exchange-Rate Hedging: Financial vs. Operational Strategies," American Economic Review Papers \& Proceedings, 91 (2), 391-395.

Bartram, S. M., Brown, G. W. and Minton, B. A., 2010, "Resolving the exposure puzzle: The many facets of exchange rate exposure," Journal of Financial Economics, 95 (2), $148-173$.

Bodnar, G. and Wong, F., 2003. "Estimating exchange rate exposures: issues in model structure," Financial Management 32 (1), 35-67.

Carter, D., Pantzalis, C. and Simkins, B. J., 2001, "Firmwide Risk Management of Foreign Exchange Exposure by U.S. Multinational Corporations," Working Paper Series. Risk Management eJournal 01/2001; DOI:10.2139/ssrn.255891.

Chiang, Yi-Chein and Lin, Hui-Ju, 2007, "Foreign Exchange Exposures, Financial and Operational Hedge Strategies of Taiwan Firms," Investment Management and Financial Innovation, 4(3), 95-105.

Döhring, B., 2008, "Hedging and invoicing strategies to reduce exchange rate exposure: a euro-area perspective," Economic Papers 299, European Commission.

Dominguez, K., 1998, "The Dollar Exposure of Japanese Companies," Journal of the Japanese International Economics, 12(4), 388-405.

Dominguez, K and Tesar, L. L. 2006, "Exchange rate exposure," Journal of International Economics, 68, 188-218.

Doukas, J.A., Hall, P. H. and Lang, L. H. P., 2003, "Exchange Rate Exposure at the Firm and Industry Level," Financial Markets, Institutions \& Instruments, 12(5), 291-346.

Friberg, R. and Wilander, F., 2008, "The Currency Denomination of Exports - A Questionnaire Study," Journal of International Economics, 75, 54-69.

Goldberg, L. S. and Tille, C., 2008, "Vehicle Currency Use in International Trade," Journal of International Economics, 76(2), 177-192.

Goldberg, L. S. and Tille, C., 2009, "Micro, Macro, and Strategic Forces in International Trade Invoicing," NBER Working Paper No. 15470, National Bureau of Economic Research.

Grassman, S., 1973, "A Fundamental Symmetry in International Payments," Journal of International Economics, 3, 105-116.

He, J. and Ng, L. K. 1998, “The Foreign Exchange Exposure of Japanese Multinational 
Corporations," Journal of Finance, 53, 733-753.

Hommel, U., 2003, "Financial versus operative hedging of currency risk," Global Finance Journal, 14(1), 1-18.

Ito, T., Koibuchi, S., Sato, K., and Shimizu, J., 2010a, "Exchange Rate Risk Management and Choice of Invoice Currency of Japanese Firms - from the 2009 RIETI Questionnaire Survey Results," RIETI Discussion Paper Series 10-J-032 (in Japanese)

Ito, T., Koibuchi, S., Sato, K., and Shimizu, J., 2010b, "Why Has the Yen Failed to Become a Dominant Invoice Currency in Asia? A Firm-Level Analysis of Japanese Exporters' Invoicing Behavior," NBER Working Paper No. 16231.

Ito, T., Koibuchi, S., Sato, K., and Shimizu, J., 2012, "The Choice of an Invoicing Currency by Globally Operating Firms: A Firm-Level Analysis of Japanese Exporters," International Journal of Finance \& Economics, 17(4), 305-320.

Jayasinghe, P., and Tsui, A. K., 2008 "Exchange rate exposure of sectoral returns and volatilities: Evidence from Japanese industrial sectors," Japan and the World Economy, 20(4), 639-660.

Kamps, A., 2006, "The Euro as Invoicing Currency in International Trade," ECB Working Paper No. 665, European Central Bank.

Page, S. A. B., 1977, "Currency of Invoicing in Merchandise Trade," National Institute Economic Review, 33, 1241-1264.

Pramborg, B., 2005, "Foreign exchange risk-management practices between Swedish and Korean firms," Pacific-Basin Finance Journal, 13, 343-366.

Pantzalis, C., Simkins, B. J., and Laux, P. A., 2001, "Operational Hedges and the Foreign Exchange Exposure of US Multinational Corporations," Journal of International Business Studies 32(44), 793-813. 
Table 1. Relation between Exchange Rate Exposure, Exchange Rate Risk Management and US dollar invoicing

Method: Least Squares with White Heteroskedasticity-Consistent Standard Errors \& Covariance

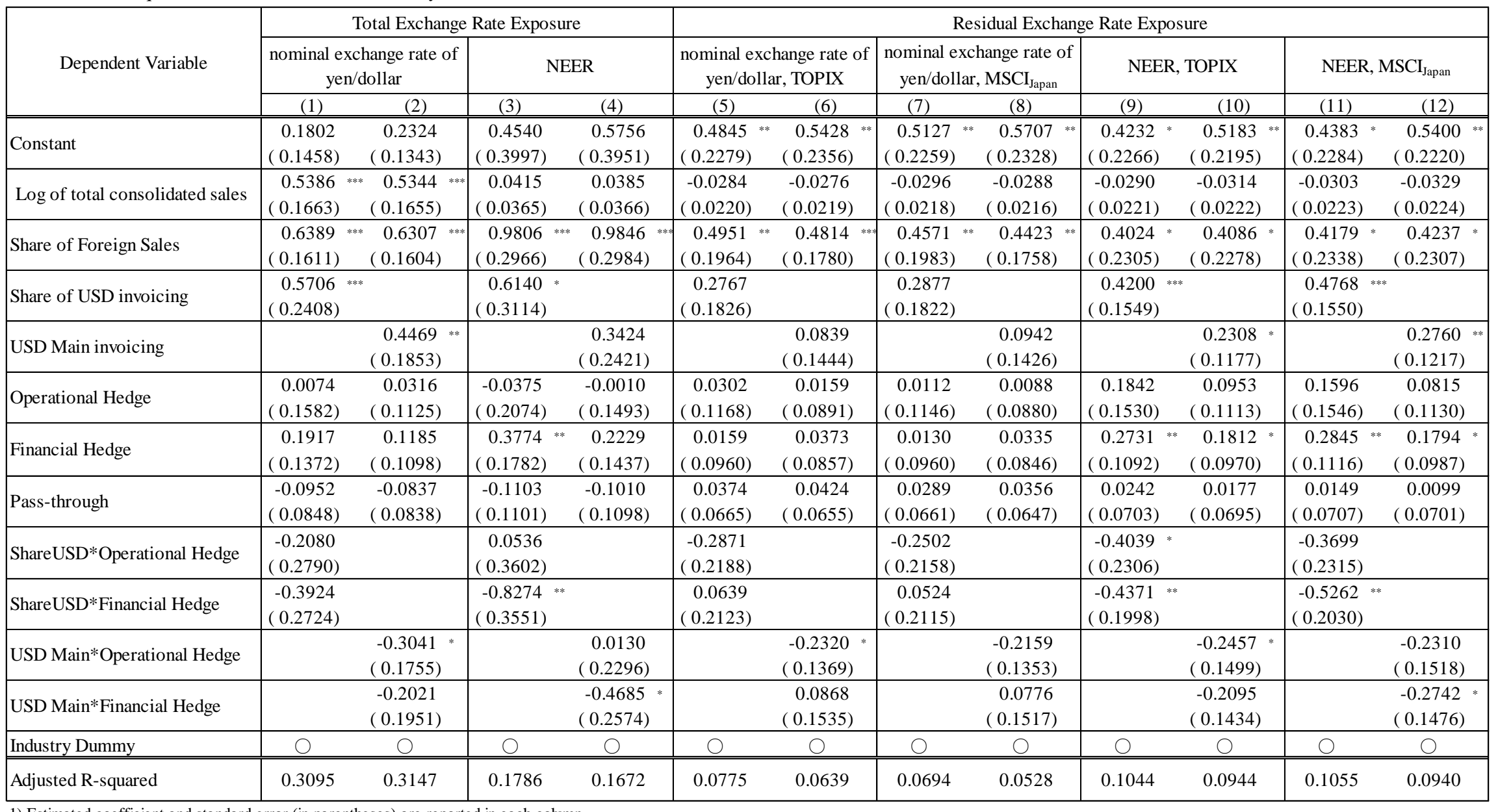

2) Asterisk(s), ***,**, and * means that the estimated coefficients are statistically significant at less than $1 \%, 5 \%$, and $10 \%$, respectively 
Table 2. Relation between Exchange Rate Exposure, Exchange Rate Risk Management and yen invoicing

Method: Least Squares with White Heteroskedasticity-Consistent Standard Errors \& Covariance

\begin{tabular}{|c|c|c|c|c|c|c|c|c|}
\hline \multirow{3}{*}{ Dependent Variable } & \multicolumn{8}{|c|}{ Residual Exchange Rate Exposure } \\
\hline & \multicolumn{2}{|c|}{$\begin{array}{c}\text { nominal exchange rate of } \\
\text { yen/dollar, TOPIX }\end{array}$} & \multicolumn{2}{|c|}{$\begin{array}{c}\text { nominal exchange rate of } \\
\text { yen/dollar, } \mathrm{MSCI}_{\mathrm{Japan}}\end{array}$} & \multicolumn{2}{|c|}{ NEER, TOPIX } & \multicolumn{2}{|c|}{ NEER, MSCI Japan } \\
\hline & (1) & (2) & (4) & (5) & (6) & (7) & (8) & (9) \\
\hline Constant & $\begin{array}{l}0.7122 \\
(0.2391)\end{array}$ & $\begin{array}{l}0.74733^{* * * * * *} \\
(0.2324)\end{array}$ & $\begin{array}{c}0.7630 \\
(0.2353)\end{array}$ & $\begin{array}{l}0.7959 \\
(0.2293)\end{array}$ & $\begin{array}{l}0.6100 \\
(0.2396)\end{array}$ & $\begin{array}{l}0.5755^{* *} \\
(0.2347)\end{array}$ & $\begin{array}{l}0.6588 \\
(0.2432)\end{array}$ & $\begin{array}{l}0.6337 \\
(0.2368)\end{array}$ \\
\hline \begin{tabular}{|l} 
Log of total \\
consolidated sales
\end{tabular} & $\begin{array}{c}-0.0287 \\
(0.0212)\end{array}$ & $\begin{array}{c}-0.0312 \\
(0.0212)\end{array}$ & $\begin{array}{c}-0.0307 \\
(0.0210)\end{array}$ & $\begin{array}{c}-0.0333 \\
(0.0209)\end{array}$ & $\begin{array}{c}-0.0320 \\
(0.0217)\end{array}$ & $\begin{array}{c}-0.0310 \\
(0.0218)\end{array}$ & $\begin{array}{c}-0.0347 \\
(0.0219)\end{array}$ & $\begin{array}{c}-0.0341 \\
(0.0220)\end{array}$ \\
\hline Share of Foreign Sales & $\begin{array}{l}0.4971 \\
(0.1983)\end{array}$ & $\begin{array}{c}0.47799^{* *} \\
(0.1926)\end{array}$ & $\begin{array}{l}0.45999^{* *} \\
(0.1997) \\
\end{array}$ & $\begin{array}{c}0.4390 * * \\
(0.1936)\end{array}$ & \begin{tabular}{|c}
0.4275 \\
$(0.2272)$
\end{tabular} & $\begin{array}{c}0.4242 * \\
(0.2263)\end{array}$ & $\begin{array}{c}0.44677^{*} \\
(0.2300)\end{array}$ & $\begin{array}{c}0.4425{ }^{*} \\
(0.2286) \\
\end{array}$ \\
\hline Share of Yen invoicing & $\begin{array}{l}-0.2020 \\
(0.1130)\end{array}$ & & $\begin{array}{l}-0.22066^{* *} \\
(0.1107)\end{array}$ & & \begin{tabular}{|c|}
-0.0415 \\
$(0.1258)$
\end{tabular} & & \begin{tabular}{|c|}
-0.0481 \\
$(0.1265)$
\end{tabular} & \\
\hline Yen Main i & & $\begin{array}{l}-0.20622^{* * * * *} \\
(0.0769)\end{array}$ & & $\begin{array}{c}-0.2202 \\
(0.0755)\end{array}$ & & $\begin{array}{c}-0.0042 \\
(0.0900) \\
\end{array}$ & & $\begin{array}{c}-0.0185 \\
(0.0901) \\
\end{array}$ \\
\hline Operational Hedge & \begin{tabular}{|c|}
-0.1057 \\
$(0.0793)$
\end{tabular} & $\begin{array}{c}-0.1252 \\
(0.0763) \\
\end{array}$ & \begin{tabular}{|c|}
-0.1083 \\
$(0.0778)$ \\
\end{tabular} & $\begin{array}{c}-0.1281 * \\
(0.0746)\end{array}$ & \begin{tabular}{|c|}
-0.0046 \\
$(0.0958)$ \\
\end{tabular} & $\begin{array}{c}0.0030 \\
(0.0927) \\
\end{array}$ & \begin{tabular}{|c|}
-0.0113 \\
$(0.0969)$ \\
\end{tabular} & $\begin{array}{c}-0.0067 \\
(0.0939) \\
\end{array}$ \\
\hline Financial Hedge & $\begin{array}{c}0.0408 \\
(0.0701)\end{array}$ & $\begin{array}{c}0.0340 \\
(0.0703)\end{array}$ & $\begin{array}{c}0.0330 \\
(0.0690)\end{array}$ & $\begin{array}{c}0.0264 \\
(0.0691)\end{array}$ & $\begin{array}{r}0.1147 \\
(0.0844) \\
\end{array}$ & $\begin{array}{c}0.1192 \\
(0.0843) \\
\end{array}$ & \begin{tabular}{|c|}
0.0944 \\
$(0.0855)$
\end{tabular} & $\begin{array}{c}0.0975 \\
(0.0854) \\
\end{array}$ \\
\hline Pass-through & $\begin{array}{r}0.0187 \\
(0.0673) \\
\end{array}$ & $\begin{array}{c}0.0083 \\
(0.0665) \\
\end{array}$ & $\begin{array}{r}0.0112 \\
(0.0670) \\
\end{array}$ & $\begin{array}{c}0.0005 \\
(0.0662) \\
\end{array}$ & $\begin{array}{r}0.0137 \\
(0.0730) \\
\end{array}$ & $\begin{array}{c}0.0162 \\
(0.0741) \\
\end{array}$ & \begin{tabular}{|c|}
0.0075 \\
$(0.0737)$ \\
\end{tabular} & $\begin{array}{c}0.0087 \\
(0.0747) \\
\end{array}$ \\
\hline Industry Dummy & 0 & 0 & $\mathrm{O}$ & $\bigcirc$ & $\mathrm{O}$ & 0 & $\mathrm{O}$ & $\mathrm{O}$ \\
\hline Adjusted R-squared & 0.0788 & 1031 & 0.0736 & 2 & 0.0796 & 39 & 0.0755 & 0.0748 \\
\hline
\end{tabular}

1) Estimated coefficient and standard error (in parentheses) are reported in each column.

2) Asterisk(s), ***,**, and $*$ means that the estimated coefficients are statistically significant at less than $1 \%, 5 \%$, and $10 \%$, respectively. 
Figure 1. Concept of Exchange Rate Risk Management

\begin{tabular}{|c|c|c|c|c|c|}
\hline $\begin{array}{c}\text { Choice of } \\
\text { Invoice currency }\end{array}$ & Operational Hedges & \multicolumn{2}{|c|}{ Financial Hedges } & \multirow{3}{*}{+} & $\begin{array}{l}\text { Pricing Policy } \\
\text { (Pass through) }\end{array}$ \\
\hline \multirow[b]{2}{*}{$\begin{array}{c}\text { Home currency } \\
\text { (Yen) } \\
\text { US dollar } \\
\text { Others }\end{array}$} & \multicolumn{2}{|c|}{ Natural Hedges } & Derivative Hedges & & \multirow[b]{2}{*}{ Yes / No } \\
\hline & $\begin{array}{l}\text { Overseas Diversification } \\
\text { Operational matching of } \\
\text { revenues and expenditure } \\
\text { (marry/netting) }\end{array}$ & $\begin{array}{c}\text { Foreign Currency } \\
\text { Debt }\end{array}$ & $\begin{array}{c}\text { Forward } \\
\text { Option } \\
\text { Others }\end{array}$ & & \\
\hline
\end{tabular}

Note: The part of "Operational hedges" and "Financial Hedges" is from Döhring (2008).

Figure 2. Total Exchange Rate Exposure by Industry

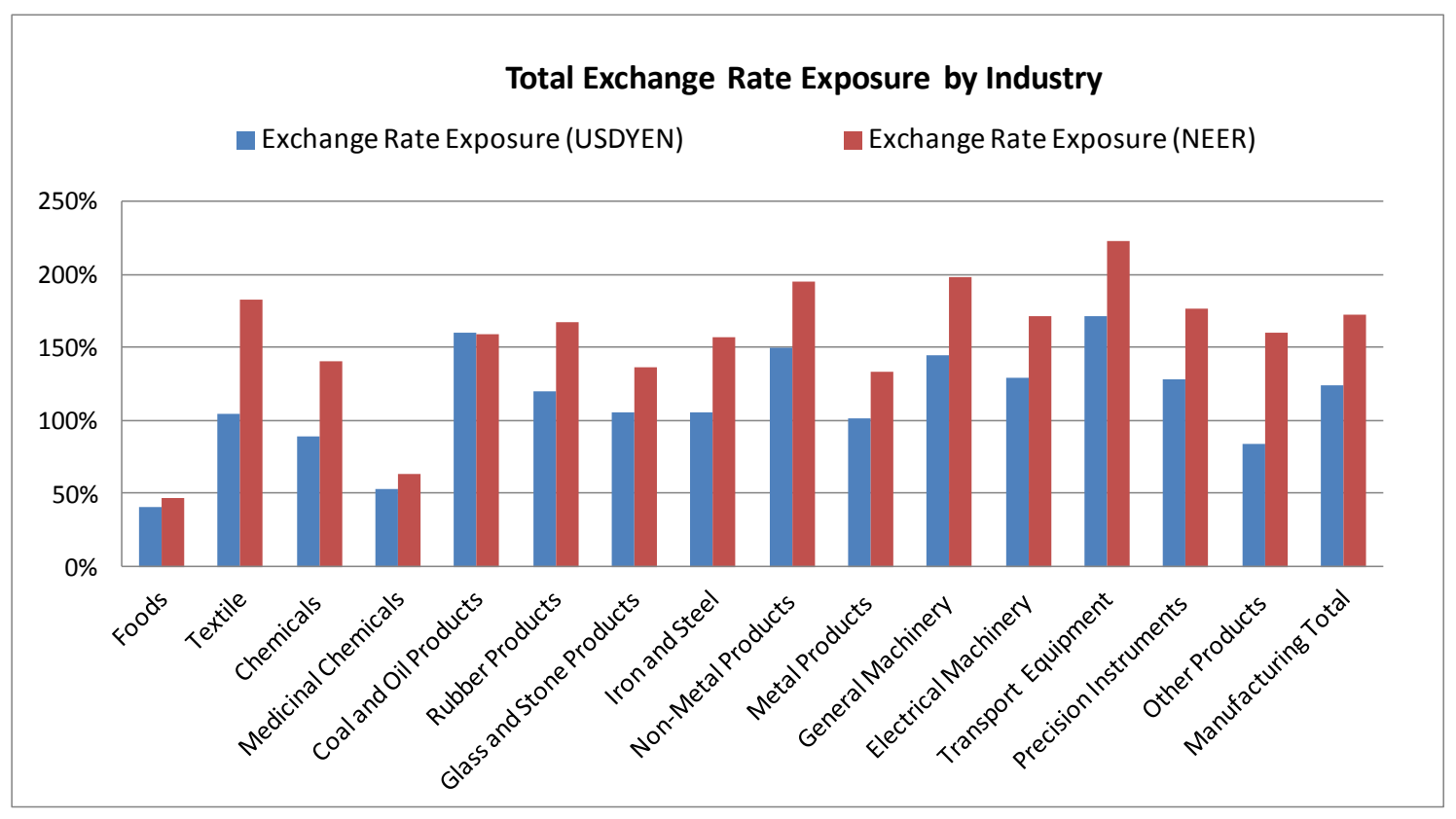

Authors' calculation

Source: The Yen/USD exchange rate is from Datastream. NEER is from BIS. 
Figure 3. Residual Exchange Rate Exposure by Industry
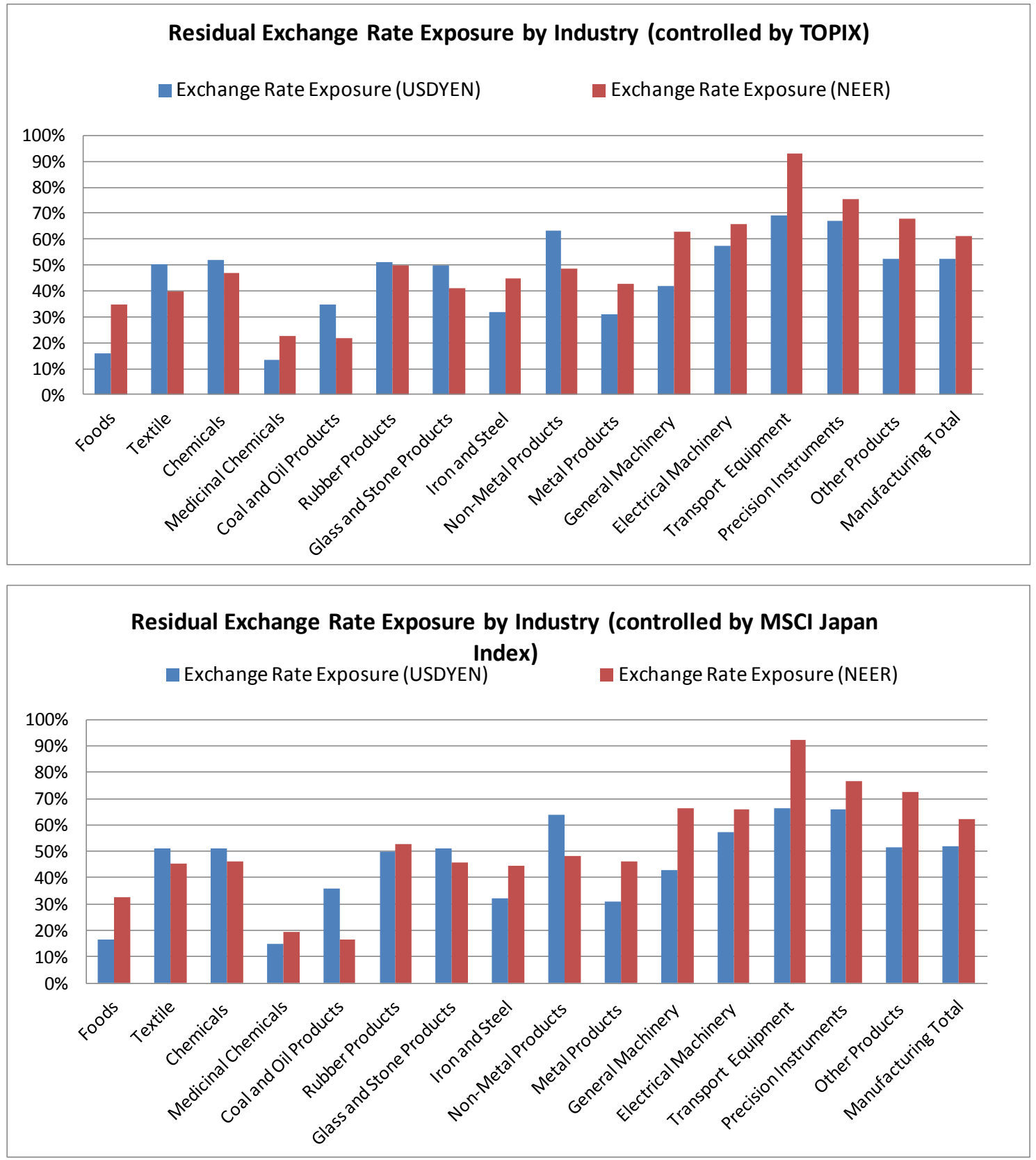

Authors' calculation

Source: Yen/USD exchange rate and TOPIX are from Datastream. NEER is from BIS. MSCI Japan index is from Bloomberg. 
Appendix 1.

Characteristic of 227 responded firms

\begin{tabular}{|c|c|c|c|c|c|}
\hline Type of Industry & $\begin{array}{c}\text { Number of } \\
\text { responded } \\
\text { firms }\end{array}$ & $\begin{array}{c}\text { Share of total } \\
\text { responded } \\
\text { firms }\end{array}$ & $\begin{array}{c}\text { Consolidated } \\
\text { Sales(Average, } \\
\text { Million Yen) }\end{array}$ & $\begin{array}{c}\text { Foreign } \\
\text { Sales(Average, } \\
\text { Million Yen) }\end{array}$ & $\begin{array}{c}\text { Foreign Sales } \\
\text { Share(Average) }\end{array}$ \\
\hline Foods & 3 & $1.3 \%$ & 483,825 & 227,374 & $32.3 \%$ \\
\hline Textiles\&Apparel & 9 & $4.0 \%$ & 102,142 & 17,585 & $23.2 \%$ \\
\hline Pulp\&Papers & 0 & $0.0 \%$ & - & - & 105,240 \\
\hline Chemicals & 36 & $15.9 \%$ & 273,090 & 22,951 & $10.5 \%$ \\
\hline Pharmaceuticals & 3 & $1.3 \%$ & 230,864 & $34.7 \%$ \\
\hline Oil\&Coal Products & 1 & $0.4 \%$ & $3,428,211$ & 399,070 & $11.6 \%$ \\
\hline Rubber Products & 4 & $1.8 \%$ & 98,511 & 47,124 & $32.2 \%$ \\
\hline Glass\&Ceramics & 6 & $2.6 \%$ & 55,315 & 25,978 & $30.3 \%$ \\
\hline Steel Products & 6 & $2.6 \%$ & 882,765 & 298,665 & $23.4 \%$ \\
\hline Nonferrous Metals & 5 & $2.2 \%$ & 203,383 & 30,943 & $17.6 \%$ \\
\hline Metal Products & 9 & $4.0 \%$ & 172,879 & 73,012 & $37.8 \%$ \\
\hline Machinery & 40 & $17.6 \%$ & 158,355 & 89,751 & $35.7 \%$ \\
\hline Electrical Machinery & 54 & $23.8 \%$ & 529,526 & 231,003 & $43.7 \%$ \\
\hline Transport Equipment & 27 & $11.9 \%$ & 888,213 & 631,035 & $41.3 \%$ \\
\hline Precision Instruments & 15 & $6.6 \%$ & 110,474 & 85,505 & $48.2 \%$ \\
\hline Other Products & 9 & $4.0 \%$ & 57,600 & 33,241 & $37.0 \%$ \\
\hline No: & 9 & & & \\
\hline
\end{tabular}

Note: Questionnaires were sent to 920 Japanese firms listed on the stock exchanges in Japan. We selected the firms that reported foreign sales in their consolidated financial statements as of fiscal year 2008, and 920 firms were finally chosen. 
Appendix 2: Descriptive statistics of all variables in section 4

\begin{tabular}{|l|rr|rr|r|}
\hline & \multicolumn{2}{|c|}{ Basic Information } & \multicolumn{2}{c|}{ Hedge Methodology } & \\
\cline { 2 - 5 } & $\begin{array}{c}\text { Log of Total } \\
\text { Consolidate } \\
\text { Sale }\end{array}$ & $\begin{array}{c}\text { Foreign Sales } \\
\text { Share (\%) }\end{array}$ & $\begin{array}{l}\text { Financial } \\
\text { Hedge* }\end{array}$ & $\begin{array}{c}\text { Operational } \\
\text { Hedge* }\end{array}$ & Pass Through* \\
\hline \hline Mean & 11.34 & 37.04 & 1.00 & 0.42 & 0.43 \\
Median & 11.21 & 35.10 & 1.00 & 0.00 & 0.00 \\
Maximum & 16.12 & 88.50 & 1.00 & 1.00 & 1.00 \\
Minimum & 8.08 & 6.80 & 0.00 & 0.00 & 0.00 \\
Std. Dev. & 1.70 & 19.82 & 0.07 & 0.50 & 0.50 \\
Observations & 207 & 206 & 207 & 203 & 191 \\
\hline
\end{tabular}

\begin{tabular}{|l|rrrr|}
\hline & \multicolumn{4}{|c|}{ Choice of Invoicing Currency } \\
\cline { 2 - 5 } & $\begin{array}{c}\text { INVOICE in } \\
\text { USD (\%) }\end{array}$ & $\begin{array}{c}\text { INVOICE in } \\
\text { YEN (\%) }\end{array}$ & USD MAIN* & YEN MAIN* \\
\hline \hline Mean & 42.32 & 47.41 & 0.35 & 0.44 \\
Median & 40.00 & 50.00 & 0.00 & 0.00 \\
Maximum & 100.00 & 100.00 & 1.00 & 1.00 \\
Minimum & 0.00 & 0.00 & 0.00 & 0.00 \\
Std. Dev. & 32.40 & 34.96 & 0.48 & 0.50 \\
Observations & 197 & 197 & 197 & 197 \\
\hline
\end{tabular}

\begin{tabular}{|l|rr|rrrr|}
\hline & \multicolumn{2}{|l|}{ Total Exchange Rate Exposure } & \multicolumn{3}{c|}{ Residual Exchange Rate Exposure } \\
\cline { 2 - 7 } & yen/dollar & NEER & $\begin{array}{c}\text { yen/dollar, } \\
\text { TOPIX }\end{array}$ & $\begin{array}{c}\text { yen/dollar, } \\
\text { MSCI }_{\text {Japan }}\end{array}$ & NEER, TOPIX & $\begin{array}{c}\text { NEER, } \\
\text { MSCI }_{\text {Japan }}\end{array}$ \\
\hline \hline Mean & 1.2370 & 1.7188 & 0.5220 & 0.5196 & 0.6115 & 0.6230 \\
Median & 1.1748 & 1.6519 & 0.4027 & 0.4091 & 0.5023 & 0.5037 \\
Maximum & 3.3893 & 4.9841 & 2.1892 & 2.2244 & 3.3997 & 3.2743 \\
Minimum & 0.0944 & 0.0192 & 0.0021 & 0.0114 & 0.0069 & 0.0008 \\
Std. Dev. & 0.6325 & 0.8091 & 0.4208 & 0.4130 & 0.5398 & 0.5374 \\
Observations & 227 & 227 & 227 & 227 & 227 & 227 \\
\hline
\end{tabular}

Authors' calculation.

Note:

1. Financial Hedge is a dummy variable which takes 1 if a firm uses a forward transaction and takes 0 if not.

2. Operational Hedge is a dummy variable which takes 1 if a firm uses a marry \& netting and takes 0 if not.

3. Pass through is a dummy variable which takes 1 if a firm changed a price due to the Yen's appreciation in 2008 and takes 0 if not.

4.USD MAIN is a dummy variable which takes 1 if the share of US dollar invoicing is higher than one of yen invoicing and takes 0 if not.

5. YEN MAIN is a dummy variable which takes 1 if the share of Yen invoicing is higher than one of US dollar invoicing and takes 0 if not. 